\title{
Nicolai Hartmann and the Metaphysical Foundation of Phylogenetic Systematics
}

\author{
Frederic Tremblay
}

Received: 22 May 2012/Accepted: 16 November 2012/Published online: 5 January 2013

(C) Konrad Lorenz Institute for Evolution and Cognition Research 2013

\begin{abstract}
When developing phylogenetic systematics, the entomologist Willi Hennig adopted elements from Nicolai Hartmann's ontology. In this historical essay I take on the task of documenting this adoption. I argue that in order to build a metaphysical foundation for phylogenetic systematics, Hennig adopted from Hartmann four main metaphysical theses. These are (1) that what is real is what is temporal; (2) that the criterion of individuality is to have duration; (3) that species are supra-individuals; and (4) that there are levels of reality, each of which may be subject to different kinds of law. Reliance on Hartmann's metaphysics allowed Hennig to ground some of the main theoretical principles of phylogenetic systematics, namely that the biological categories-from the semaphoront to the highest rank-have reality and individuality despite not being universals, and that they form a hierarchy of levels, each of which may require different kinds of explanation. Hartmann's metaphysics thereby provided a philosophical justification for Hennig's phylogenetic systematics, both as a theory and as a method of classification.
\end{abstract}

Keywords Nicolai Hartmann · Willi Hennig · Metaphysics · Ontology · Phylogenetic systematics · Species

A distinguishing feature of 20th-century philosophy is the conception that the categories of time and process are somehow more fundamental than they were conceived to

F. Tremblay $(\varangle)$

Department of Philosophy, SUNY Buffalo, Buffalo, NY, USA

e-mail: ft4@buffalo.edu be by traditional metaphysics. This view is characteristic of philosophers such as Bergson, Heidegger, Whitehead, and Nicolai Hartmann. Hartmann harnessed and applied this thesis to the analysis of the categories of reality, including biological categories. The ensuing ontology made possible the metaphysical foundation of temporally and processually oriented scientific theories. Phylogenetic systematics is the method of classifying biological categories according to genealogical relations on a tree-like diagram. This method was originally developed by the entomologist Willi Hennig to classify biological categories in a way that takes evolution into account. In Grundzüge einer Theorie der Phylogenetischen Systematik (1950) and Phylogenetic Systematics (1966) Hennig is markedly concerned with grounding phylogenetic systematics on a metaphysical foundation. I claim that to carry this project through he sought support in Hartmann's ontology.

Some authors have reported an influence of Hartmann on Hennig, including Edward Wiley and Richard Mayden (1985), Olivier Rieppel (2006, 2007, 2009), John Wilkins (2009), Wolf-Ernst Reif (2010), Gustavo Caponi (2010), and Andrew Hamilton (2011). The word "influence," however, may be too strong; it is difficult to determine with certainty whether there is an actual influence or whether Hennig is using Hartmann as an authority. It could be that Hennig simply relied on Hartmann because, as Konrad Lorenz remarked, Hartmann's "views on the structure of the material world, especially the world of organisms, correspond ... exactly to those of the phylogeneticist" (1977, p. 37). But, regardless of whether he is influenced by Hartmann in the strict sense of the word, Hennig certainly adopts and uses elements of Hartmann's philosophy. In this essay I take on the task of documenting Hennig's adoption and application of some of Hartmann's ideas. 


\section{Hennig and Metaphysics}

\section{According to Darwin,}

the natural system is founded on descent with modification; all true classification is genealogical; community of descent is the hidden bond which naturalists have been unconsciously seeking, and not some unknown plan of creation, or the enunciation of general propositions, and the mere putting together and separating objects more or less alike. ...the arrangement of the groups within each class, in due subordination and relation to the other groups, must be strictly genealogical in order to be natural. (Darwin 1859, p. 420)

It was nearly a century later that the method of the natural system of classification Darwin dreamt of was developed by Hennig. As Edward Wiley says, "Hennig accomplished the task of developing the genealogical system called for by Darwin" (1981, p. 193).

In his elaboration of this genealogical system, Hennig was exceptionally concerned with metaphysical issues. As the German biologist Wolff-Ernst Reif commented, "Hennig's contemporaries probably did not understand ... why he dealt with the rather difficult ontological discussions of the philosophers Nicolai Hartmann and Ludwig von Bertalanffy" (2010, p. 229). It was not uncommon for 20th-century German biologists to be concerned with philosophical issues. Some of this was a result of the interdisciplinary tendency in the academic culture of Germany at that time. But in Hennig's case it was necessary given the revolutionary character of his work, which required him to base his methodology on solid metaphysical grounds.

At the beginning of the 20th century German systematics was still dominated by morphological idealism-a kind of systematics based on the identification of relations of similarity. But for Hennig phylogenetic systematics has priority over idealistic morphology, because genetic relations-which are real relations existing independently of the subject observing them-are existentially prior to relations of similarity (1966, pp. 11-12). Relations of similarity can mislead the perceiving subject; two groups of organisms could superficially look alike, yet be genetically distant from each other. For instance, larvae have been classified as species of worms on the basis of similarities, but once their genetic relations were discovered it became obvious that they could not be defined as worms. Hennig is not arguing that phylogenetic systematics should be the only system of biological systematics, but that it should be its "general reference system" (1966, p. 23).

For this reason, Hennig had to show-against idealistic morphology — that biological reality is better captured by the description of genetic relations and their classification on the temporal dimension than by the mere identification and classification of static relations of similarity. He also had to overcome the pre-Darwinian conception that biological categories are universals, because universals are traditionally conceived as static and Darwin has shown that species evolve. And, finally, he had to show-against the conceptualistic and nominalistic theories of species of his time-that, despite not being universals, biological categories are nevertheless real, i.e., have a mind-independent existence.

Thus, he needed to ground phylogenetic systematics in a dynamic and realistic ontology justifying his view that the best kind of representation of biological categories is through the description of genealogical relations on the temporal dimension as well as justifying his thesis that biological categories are real entities despite not being universals. I claim that in his search for a Darwinian and realistic metaphysical foundation Hennig found support in Hartmann's ontology, among other sources. I identify four main theses that he adopts from Hartmann: (1) the real is what is temporal; (2) to be an individual is to have duration; (3) species are supra-individuals; and (4) there are levels of reality, each of which may be subject to different kinds of law. ${ }^{1}$

\section{The Real is What is Temporal}

For Hartmann, reality is made up of four irreducible levels (Schichten): the inorganic level (anorganische Schicht) containing categories such as atoms, molecules, planets, and stars, as well as their properties and processes; the organic level (organische Schicht) containing organological categories such as cells and unicellular organisms, multicellular organisms, species, genera, families, orders,

\footnotetext{
${ }^{1}$ In (1950) and (1966), Hennig cites only one text from the writings of Hartmann: "Neue Wege der Ontologie." This essay was first published in 1942 in a collective book entitled Systematische Philosophie, of which Hartmann was the editor. This volume also includes essays by Arnold Gehlen, Erich Rothacker, Otto Friedrich Bollnow, Hermann Wein, and Heinz Heimsoeth. It may be worthy of note that Hennig also refers to Gehlen's and Wein's essays from this volume (Hennig 1966, p. 11). This shows that he has read at least some essays from the volume and is not merely quoting it from secondary sources. In Grundzüge einer Theorie der Phylogenetischen Systematik (1950), Hennig also quotes N. Hartmann indirectly from J. W. Harms (Wandlungen des Artgefüges, 1934) who himself quotes N. Hartmann from Max Hartmann's Biologie und Philosophie (1925) who quotes N. Hartmann's Philosophische Grundfragen der Biologie (1912). So Hennig also quotes Hartmann's Philosophische Grundfragen der Biologie from secondary sources. Hennig may have read other works from Hartmann, but in this article I assume only that he read "Neue Wege der Ontologie" and those sections of Philosophische Grundfragen der Biologie to which he had indirect access.
} 
etc., their properties and processes; the psychic level (seelische Schicht) containing categories such as emotional and non-conscious cognitive processes; and the level of cultural production (geistige Schicht) containing categories such as the conscious intellective processes of individuals, as well as the historical and cultural processes of institutions, nations, and mankind. This sequence of levels forms a hierarchy in which the existence of the higher levels depends on that of the lower ones.

Given this analysis, the dimensional category of time pervades more levels than the dimensional category of space. Whereas only inorganic and organic beings can be extended in space, everything that is real exists in time. Mental activities and historical processes, for instance, are extended in time but not in space. Considering that an entity extended in space must necessarily also be in time but that an entity extended in time need not be extended in space, Hartmann infers that time pervades more levels of reality than space. Thus, Hartmann further concludes, the essential characteristic of reality is to be extended in time. Here is some textual evidence:

- "Not only matter is real, however. It is not spatiality that is the distinctive (specific) characteristic of the real, but rather time." 2

- "Time connects everything that is real-whether thing or event, organic or mental life." 3

- "Everything real is in time and only a part of it is in space." 4

- "The new concept of reality does not depend on materiality and spatiality, but only on temporality, processuality, and individuality." 5

- "Temporality is the main characteristic of reality. The principle of time towers up in the higher levels of reality, whereas space already breaks off on the boundary between the organic and the psychic." 6

Hartmann applies this criterion to the analysis of various categories, including that of biological species. The reality

\footnotetext{
2 "Real aber ist nicht Materie allein. Nicht die Räumlichkeit ist das unterscheidende (spezifische) Merkmal der Realen, sondern die Zeit" (Hartmann 1935, p. 185). Unless otherwise indicated, all translations are mine.

3 “[D]ie Zeit ... verbinder alles Reale-einerlei, ob Dinge oder Geschehnisse, organisches oder seelisches Leben" (Hartmann 1938, p. 9).

4 "In der Zeit eben ist alles Reale, im Raume nur ein Teil" (Hartmann 1942, p. 218).

5 "Der neue Realitätsbegriff hängt nicht an Materialität und Räumlichkeit, sondern lediglich an der Zeitlichkeit, Prozessualität und Individualität" (Hartmann 1949, p. 784).

6 “ $[\mathrm{D}] \mathrm{a} ß$ Zeitlichkeit geradezu das Hauptmerkmal des Realen ist. Das Zeitprinzip seinerseits ragt in die höheren Realschichten hinauf, während der Raum bereits an der Grenze des Organischen und Seelischen abbricht" (Hartmann 1950, p. 217).
}

of species is often regarded with suspicion because we cannot encounter them in space; if they were real, people think, they would be as tangible as the things we encounter in space. But since, for Hartmann, spatial extension is not a necessary condition for being real, he can say that species are real by virtue of being extended in time. ${ }^{7}$

One of Hennig's main metaphysical concerns in Grundzüge einer Theorie der phylogenetischen Systematik and Phylogenetic Systematics is the issue of the reality of species and higher biological categories. As he says, "A general question that remains to be answered before we turn to the special methods of phylogenetic systematics is the reality (Realität) of the different group categories (Gruppenkategorien) of the system. Opinions are still divided on this" (Hennig 1966, p. 77; 1982, p. 81). More specifically, the issue is whether the categories "have 'real existence' (reale Existenz) or not, whether they have the character of individuality (Individualitätscharakter) or are general concepts (Allgemeinbegriffe)" (Hennig 1966, p. 78; 1982, p. 82). According to the biologists Stefan Richter and Rudolf Meier, the issue of "whether [taxonomic groups] are 'real' is central to Hennig's argument" (1994, p. 213).

Hennig is well aware of the philosophical nature of the issue. As he says, the "debate over the reality of the supraindividual groupings of the biological system would lead us back to the controversy over universals, which played an important part in history, especially in the philosophy of the Middle Ages (existence of universals ante rem, in re, or post rem)." 8

Hennig surveys all sides of the debate. He says that some, like Ernst Haeckel, admit as real only the highest subdivisions of the plant and animal kingdoms (Hennig 1966, p. 77). Others, such as Ludwig Plate, Bernhard Rensch, and Alfred Kinsey think that only individual organisms and species are real and that the higher categories (genus, family, order, etc.) are "mere abstractions" (bloße Abstraktionen). ${ }^{9}$ Rensch distinguishes between "objective" and "subjective" categories, and classifies the species and lower categories as objective and all higher categories as subjective (Hennig 1966, p. 78). Another view, embraced by Erich Martini, is that only individual organisms are real and that everything from species upward are just concepts (Begriffe) (Hennig 1966, p. 78; 1982, p. 82).

Hennig's own stance is that the "categories of phylogenetic systematics are not constructed by abstraction"

\footnotetext{
${ }^{7}$ On this, see the discussion about the reality of the life of the species in Hartmann (1950, pp. 561-564).

8 I had to revise Davis \& Zangerl's translation here (Hennig 1966, p. $79 ; 1982$, p. 82 ).

9 “... die höheren taxonomischen Gruppenkategorien bloße Abstraktionen seien” (Hennig 1982, p. 81). See also Hennig 1966, p. 78.
} 
(1966, p. 79). ${ }^{10}$ In other words, "the higher groups of the phylogenetic system are not mere intentional beings." 11 Rather, in "the phylogenetic system the categories at all levels are determined by genetic relations that exist among their subcategories. Knowledge of these relations is a prerequisite for constructing the categories, but the relations exist whether they are recognized or not" (Hennig 1966, pp. 79-80). ${ }^{12}$ To prove that phylogenetic categories are more than mere abstractions and concepts, Hennig has to show that they satisfy a criterion of reality, which he finds in Nicolai Hartmann's philosophy:

according to N. Hartmann (who is followed almost without reservation by Max Hartmann in his work on the philosophy of the natural sciences), temporality is the only characteristic of reality and individuality: "The true characteristics of reality are not dependent on the categories of space and matter, but on those of time and individuality. And temporality is inseparably connected with individuality. It consists in nothing else but onceness and singleness" (N. Hartmann 1942). By reality Hartmann understands "the mode of existence of everything that has a place and a duration in time, its origins and its cessation." (Hennig 1966, p. 81) ${ }^{13}$

The first passage that Hennig quotes here is from Hartmann's "Neue Wege der Ontologie" (1942, p. 218). The second is from the German neurologist and psychiatrist Theodor

\footnotetext{
10 "Die Kategorien der phylogenetischen Systematik werden nicht gebiltet durch Abstraktion" (Hennig 1982, p. 83).

11 “... den höheren Gruppen des phylogenetischen Systems nicht ein bloß intentionales Sein zukommt" (Hennig 1950, p. 120).

12 "Im phylogenetischen System sind die Kategorien aller Stufen bestimmt durch genetische Beziehungen, die zwischen ihren Unterkategorien bestehen. Die Kenntnis dieser Beziehungen ist Voraussetzung für die Bildung der Kategorien, aber an sich bestehen sie, ob sie erkannt werden oder nicht" (Hennig 1982, p. 83).

13 I slightly modified Davis \& Zangerl's translation here. The original text is: "Nun ist nach N. Hartmann (dem ja auch Max Hartmann in seinen Arbeiten zur Philosophie der Naturwissensschaften stets fast verbehaltos folgt) Zeitlichkeit das einzige Merkmal der Realität und Individualität: „Die wahren Merkmale der Realität hängen nicht an den Kategorien des Raumes und der Materie, sondern an denen der Zeit und der Individualität. Und mit der Zeitlichkeit hängt untrennbar die Individualität zusammen. Sie besteht in nichts anderem als in der Einmaligkeit und Einzigkeit" (N. Hartmann 1942). Unter Realität versteht Hartmann ,die Seinsweise alles dessen, was in der Zeit eine Stelle oder Dauer, sein Entstehen und Vergehen hat (Ziehen II, p. 146)" (Hennig 1982, p. 84). A similar passage is already present in the 1950 version: "Die wahren Merkmale der Realität hängen nicht an den Kategorien des Raumes und der Materie, sondern an denen der Zeit und der Individualität. Und mit der Zeitlichkeit hängt untrennbar die Individualität zusammen. Sie besteht in nichts anderem als in der Einmaligkeit und Einzigkeit" (N. Hartmann 1942). Unter Realität versteht Hartmann „die Seinsweise alles dessen, was in der Zeit eine Stelle oder Dauer, sein Entstehen und Vergehen hat" (Ziehen II, p. 146)" (Hennig 1950, p. 115).
}

Ziehen's Erkenntnistheorie (1939, p. 146); it is from a short section of the book where Ziehen presents and discusses Hartmann's ontological system (Ziehen 1939, pp. 146-148). Manifestly, Hennig seeks to provide support from an authority other than himself for his own interpretation of Hartmann. The reference mysteriously disappeared in the 1966 version, but it is already present in 1950 and is still present in the German manuscript of the 1966 version posthumously published in 1982 by Hennig's eldest son Wolfgang Hennig (Hennig 1982, p. 84).

Does Hennig's concept of species and other biological categories satisfy the Hartmannian criterion for reality? It does. Hennig says "[t]here can be no doubt that, like the higher categories of the phylogenetic system or of any other divisional hierarchy, [species] have "place or duration in time' (Stelle oder Dauer in der Zeit)" (1966, p. 83; 1982, p. 86). Here Hennig puts "place or duration in time" in quotation marks to indicate that he is satisfying Hartmann's criterion as earlier quoted from Ziehen. Now that his theory has met this criterion, Hennig can claim that species and higher-order biological categories are not mere abstractions or concepts, but that they are real. The following passage confirms this reading:

If we now attempt to evaluate the categories of the phylogenetic system from the viewpoint thus gained [i.e., gained from Nicolai Hartmann's account], there can be no doubt that all the supra-individual categories, from the species to the highest category rank, have individuality and reality. They are all ... segments of the temporal stream of successive "interbreeding populations.” (Hennig 1966, p. 81)

Relying on the Hartmannian thesis that the real is what is temporal makes it possible for Hennig to argue that phylogenetic systematics is the classification system that is best suited for the description of organic reality. For biological categories such as species, genera, families, and orders are extended on the temporal dimension, and phylogenetic systematics is the only biological methodology geared for representing categories that are extended in time and their temporal relations.

Moreover, according to Hennig, representation along the temporal dimension is more accurate and unmistakable than representation along other dimensions: "In this dimension both the ontogenetic relations of the different life-stages of the individual (the semaphoronts), and the genealogical (tokogenetic) relations of the individuals and the phylogenetic relations of the species, can be represented with complete accuracy (zutreffend) and unmistakably (unmißvertändlich)" (Hennig 1966, p. 26, translation modified; 1982, p. 33). The other dimensions such as the morphological, the ethological, the physiological, and the chorological are less commensurable, so things in other 
dimensions cannot be represented with as much accuracy and as unmistakably as in the temporal one (Hennig 1966, p. 26). Thus, Hennig's appeal to Hartmann's thesis that the real is what is temporal allows him to support the thesis of the pre-eminence of a classificatory system that captures temporally extended entities.

\section{To Be an Individual is to Have Duration}

Individuality has traditionally often been conceived as the characteristic of what is extended in space and can be pointed at. Hartmann proposed a different notion of individuality. Since for him everything that is real is temporal but not necessarily spatial, the criterion of individuality has to be strictly temporal. In fact, time is itself a "principle of partition" (Prinzip der Trennung) (Hartmann 1938, p. 5). It allows for partition into discrete durations. Hartmann's criterion of individuality is thus to have duration. Something remains identical with itself as long as it lasts. In other words, to be an individual is to have temporal boundaries, i.e., to have a beginning and an end. Hartmann will eventually apply this criterion to the categorial analysis of a variety of kinds of entities. In Ethik, for instance, he says that a "person" is an individual, not because it is a spatially extended body, but because he or she, among other criteria, "exists only once." ${ }^{14}$ For the same reason, communities and institutions are also individuals. ${ }^{15}$ Indeed,

[t]here are in fact spiritual collective entities; there is an "objective spirit"- even if not in the Hegelian sense .... In this sense, art, science, the morality of an age, the life of a nation, political or religious lives, are collective spirits. The mode of existence of such entities is a thoroughly real one, as they have their beginning and end. (Hartmann 1926, p. 245, my italics $)^{16}$

In the case of individual organisms, their coming into being is the end of their ontogenesis. The ontogenetic process, according to Hartmann, is directed toward a finality, which is the attainment of a specific form, and the ontogenetic process is over when the form is completed (1950, p. 626). Death, on the other hand, ensues from the

\footnotetext{
14 “ist nur einmal ... vorhanden" (Hartmann 1926, p. 469).

15 "Individuell ist auch ein Gemeinwesen, eine Institution" (Hartmann 1926, p. 463).

16 "Es gibt freilich geistige Gesamtgebilde, „objektiven Geist“wenn auch nicht im Hegelschen Sinne .... Die Kunst, Wissenschaft, Moralität einer Zeit, das nationale, politische oder religiöse Leben ist Gesamtgeist in diesem Sinne. Die Seinsweise solcher Gebilde ist eine durchaus realer, wie sie denn ihr Entstehen und Vergehen ... haben" (Hartmann 1926, p. 245).
}

absence of essential forms, processes, or functions. Because the process has the function of maintaining the form, without any of these the organism is no longer an organized system (Hartmann 1950, p. 518). As he says, death is "the collapse of the system of interrelated functions, its disorganization, the cessation of the processes" (1950, p. 518).

Species also have their temporal boundaries, which are events of speciation (Hartmann 1950, p. 613). For Hartmann, speciation is not a mere alteration of superficial characteristics, but a pervasive kind of change that involves the acquisition of new organic traits (p. 614). He compares species to the branches of a tree: all the branches are individual species connected to chronologically prior or posterior individual species through their beginnings and ends. And he compares the process of extinction to the truncation of the branches of a tree: life clings to the trunk and the main branches, and those that are normally truncated are the highest and most sophisticated ones (p. 613).

Hennig agrees with Hartmann that to be an individual is to have "a place or a duration in time (in der Zeit eine Stelle oder Dauer)" (Hennig 1966, p. 81; 1982, p. 84); and to have a "beginning and an end in time (Beginn und Ende in der Zeit)" (Hennig 1966, p. 81; 1982, p. 85). For him, "the space-matter (bodily) relationship of the parts is not decisive for the concept of individuality" (Hennig 1966, p. 81). His appeal to Hartmann serves to support his own conclusion that all biological categories from the semaphoront up to the highest rank are real individuals (p. 83).

Let us begin by considering the individuality of the most elementary category: the semaphoront. For Hennig, the "semaphoront (the character bearer) must be regarded as the element of systematics" (1966, p. 65). Hennig introduced this idea in "Probleme der biologischen Systematik" (1947), where he says that "the 'bearers of characteristics' (Merkmalsträger) are the veritable elements of systematic work, i.e., the shorter time-spans within the individual's lives during which neither they nor for that matter their relations to others change" (p. 276). ${ }^{17}$ The Merkmalsträger is the phase of a given organism. In 1950, Hennig coins the word "semaphoront" (Semaphoront) to express this idea. ${ }^{18}$ He defines "semaphoront" as "an individual over a time interval (Zeitspanne), however short (although not a 'point

\footnotetext{
17 "sind die „Merkmalsträger“ die wahren Elemente der systematischen Arbeit, d. h. die Individuen innerhalb kurzer Zeitspannen ihres Lebens, im Verlaufe deren sie sich selbst und damit ihre Beziehungen zu anderen nicht verändern" (Hennig 1947, p. 276).

18 The word is formed from the Greek sêma, which means "character," and phoros, which means "bearer" (Hennig 1950, p. 9; see also Hennig 1966, p. 6). He sometimes uses the expression Merkmalsträger-Semaphoront, which is in fact tautological, because Semaphoront expresses the same meaning as Merkmalsträger, only using Greek roots.
} 
in time'), of its life." ${ }^{19}$ It is a unity (Einheit) smaller than the life of the organism of which it is a part and a metamorphosis-stage (Metamorphose-stadium) (1950, p. 9).

Thus defined, the semaphoront is not an individual in the traditional sense, yet it is one in Hartmann's sense. For instance, we can admit that the caterpillar is an individual distinct from the butterfly only if we accept the thesis that something is an individual in virtue of having duration and that the event of metamorphosis is a boundary that marks the end of one phase and the beginning of another. Without this criterion, the semaphoront could not be recognized as a real individual. It is thus manifest that the semaphoront satisfies Hartmann's criterion. And since Hartmann's criterion is what justifies the notion of semaphoront, it is at least probable that this criterion is at the very root of the notion of semaphoront.

Per contra, Olivier Rieppel looked for an influence on Hennig's conception of the semaphoront in Theodor Ziehen's theory of cognition. Rieppel sees a precursor of the idea of semaphoront in Ziehen's concept of the "reduction of the gignomen." As Rieppel says, "Ziehen's reduction process [sc., of the gignomen] can ... be seen to lie at the root of Hennig's (1950, p. 6) concept of the semaphoront" (2003, p. 169). Gignomen is Greek for "becoming" (das Werdende) (Ziehen 1934, p. 3). Ziehen identifies the gignomen with the given (das Gegeben). He also identifies the given with the psychic (das Psychische). In fact, for him "psychic is just another word for the given." ${ }^{20}$ If the given is psychic, and the gignomen is identical with the given, then the gignomen is psychic, too. As Ziehen says, "all gignomene are psychic." ${ }^{21} \mathrm{He}$ also describes the gignomen as "an activity of "inner apprehension'." 22 Ziehen labels his own view as a "psychomonism," a "panpsychism," and a "consciousness-monism." 23 And he specifies that he uses the expressions "panpsychism" and "idealism" in the same sense (1915, p. 8, note 2).

In light of this, I find questionable Rieppel's claim that Ziehen's gignomen lies at the root of Hennig's concept of semaphoront. Ziehen's gignomen is an activity of inner apprehension. If the semaphoront were an activity of inner apprehension, it would not have an existence independent of that apprehension. And Hennig would not have accepted the thesis that the semaphoront is a mind-dependent entity of any sort. For Hennig the phylogenetic categories are

\footnotetext{
19 "Die Definition des Semaphoronten als des Individuums während einer, allerdings sehr kleinen, Zeitspanne (nicht ,an einem Zeitpunkte“) seines Lebens" (Hennig 1950, p. 9).

20 "Das Psychische ist eben nur ein anderes Wort für das Gegebene" (Ziehen 1915, p. 9).

21 "[A]lle Gignomene sind psychisch" (p. 6).

22 “[E]in Vorgang ,innerer Wahrnehmung “” (Ziehen 1934, p. 4).

23 "Psychomonismus," "Pampsychismus," "Bewußtseinsmonismus" (Ziehen 1934, p. 6, note 1; 1915, pp. 9, 213).
}

real, i.e., their existence does not depend on perceiving or apprehending minds. And since the semaphoront is one of the phylogenetic categories, it cannot be a mere activity of inner apprehension-it must be something independent of this apprehension. Although it is possible that Hennig found some inspiration in Ziehen, I think it is more probable that he sought the philosophical criterion for the reality and individuality of semaphoronts in Hartmann's realistic ontology rather than in Ziehen's idealistic theory of cognition.

Hartmann's criterion also applies to species and higherorder biological entities such as families, orders, classes, and phyla. If the latter are to be real individuals, as Hennig would have it, they must conform to Hartmann's criterion of individuality, i.e., they must come into being, have a certain duration, and pass away. Hartmann said that in the case of species the principle of individuation is speciation. Hennig agrees with this, which supports the phylogenetic hypothesis, and he even tries to show that his treatment of biological categories conforms to Hartmann's criterion when he says that "the categories of the phylogenetic system ... have a beginning and an end in time (N. Hartmann)" (1966, p. 81). Here, he writes "N. Hartmann" in parentheses presumably to indicate that his concept of biological categories qua individuals satisfies Hartmann's criterion of individuality.

In Phylogenetic Systematics Hennig contrasts Hartmann's criterion to Bertalanffy's, and defends the former over the latter. For Bertalanffy, to be an individual is to be a "unity of causal interactions" (Wirkungseinheit). The idea that an individual is a unity of causal interactions implies that every individual has material parts that have functions with regards to the other parts. Hennig interprets the idea of unity of causal interactions as meaning that an individual can be a causal unity internally (von innen), as when the organs of an organism are causal agents for other parts of the organism, and externally (nach außen), as when an organism has effects on other organisms or its environment (Hennig 1966, p. 82; 1982, p. 86). Thus, according to Hennig's reading of Bertalanffy, something is an individual if it has causal powers, whether internal, external, or both.

To determine whether Hartmann's or Bertalanffy's criterion is the correct one, Hennig takes the example of unicellular organisms. Unicellular organisms satisfy both criteria. But what if we take clones? For Hennig the word "clone" denotes a group of protozoan cells descending from the same uniparental cellular organism. ${ }^{24}$ According to him, clones satisfy Hartmann's criterion, but not that of Bertalanffy. As he says, "[i]n their totality as a clone

\footnotetext{
$\overline{24}$ The word "clone" is equivocal. For a study of the history of its many meanings, see Mittwoch (2002).
} 
(Klon) they [sc., the asexually produced offspring of protozoa] also possess individuality (Individualität) and real existence (reales Sein) in N. Hartmann's sense, but the clone lacks the character 'unity of causal interactions' (Wirkungseinheit)" (Hennig 1966, p. 82, translation modified; 1982, p. 86). Clones, as defined above, do not constitute unities of causal interactions, i.e., their parts are not causally related to one another, yet they have duration. Thus, whereas Bertalanffy's criterion applies successfully to organisms and phases of organisms, it fails to apply to entities such as clones.

Moreover, it isn't clear whether Bertalanffy's criterion applies to higher-order biological categories either. As Hennig puts it, "[t]here can be no doubt that, like the higher categories of the phylogenetic system, [species] have 'place and duration in time'. It is questionable, however, whether the species can be regarded as unities of causal interactions within their environment" (1966, p. 83). Not all biological categories have the character of being unities of causal interactions; only individual organisms and their phases clearly do. Yet all have duration. Since the criterion of having duration implies having a beginning and an end, and that it isn't always clear where beginnings and ends are to be found-especially in the case of asexually reproducing organisms-Hennig cautiously admits that it might not apply to all organisms (1966, p. 66). Hartmann's criterion is nevertheless the criterion of individuality that applies to the greater number of biological categories. And since Hartmann's criterion applies to more biological categories than Bertalanffy's, Hennig concludes that in phylogenetic systematics Hartmann's criterion must have priority over Bertalanffy's. ${ }^{25}$

That all biological categories must have a beginning, duration, and end is also necessary for the very possibility of phylogenetics as a method. For without beginnings and ends there is no cleavage, and without cleavage is lost the possibility of classifying species in a graphic representation that stands for temporal relations. As Hennig says, "[s]uch a picture of phylogenetic relationships can be a system of hierarchic type only if in its plan of construction the species is regarded as the unit that undergoes division. This is possible only if two successive processes of species cleavage (Artspaltungsvorgänge) are assumed to be the temporal delimitation (zeitliche Begrenzung) of its existence" (1966, p. 64, translation modified; 1982, p. 69). Therefore, only if species have more or less definite

\footnotetext{
25 Hamilton acknowledges Hennig's adoption of Hartmann's criterion of individuality: "Hennig was very well aware that part of what it means to be an individual is to have a beginning and end in time. Indeed, following Hartmann (1942), he argued that duration in time is the most important feature for individuating spatially scattered individuals: "temporality is the only characteristic of reality and individuality' (Hennig 1966, p. 81)" (Hamilton 2011, p. 8).
}

beginnings and ends can they be elements of the phylogenetic system. It thus seems like prior agreement with the Hartmannian criterion of individuality is a necessary condition for agreeing with Hennig's phylogenetic systematics both as a theory and as a method.

\section{Species are Supra-individuals}

Hartmann's theory of categories contains twelve pairs of fundamental opposite categories. One of these pairs is the opposition "element-system" (Element-Gefüge). ${ }^{26}$ "Element" and "system" are relative categories, which means that neither can exist without the other. A system is a stable processual structure of elements that can itself be an element for a higher-order system. In Der Aufbau der realen Welt, Hartmann distinguishes between merely "dynamic systems" and "organic systems." For instance, electrons, protons, and neutrons can be elements for a dynamic system, namely the atom. In turn, atoms can be elements for a higher-order dynamic system, i.e., the molecule. In the same way, planets, which are dynamic systems, can also be elements for higher-order dynamic systems such as solar systems, and solar systems can be elements for galaxies, etc. Things such as cells, multicellular organisms, and species, are organic systems. For instance, a cell is itself an organic system, but it is also an element for a higher-order organic system, the multicellular organism (Hartmann 1940, Chapt. 33).

For Hartmann, the individual organism is an organic system of three kinds of entities: processes, forms, and functions. The process is the maintenance of the form, once it is already acquired through ontogenesis. The function is the role of the organs, the task of which is to maintain the processes that maintain the form. The matter from which the organism is constituted is not properly speaking an integral part of the organic system, for it is constantly gained and lost, and it is nothing else than what is already to be found at the inorganic level. What persists in the organic system and is novel to the organic level is the threefold structure of processes, forms, and functions that keep together inorganic matter. The individual organism is the unity and organic system of these three categories (Hartmann 1950, p. 517).

A species, in contrast, is an organic system composed only of individual processes of life. The lives of all the individuals of a same lineage constitute a system of lives, and this system is the species. Hartmann thus defines "species" as a "system of a higher-order" (Gefüge höherer Ordnung) and a "supra-individual life" (überindividuelle

\footnotetext{
${ }^{26}$ For a justification of the translation of the word Gefüge by 'system' see Tremblay (2011, p. 128, n. 2).
} 
Leben) (1950, pp. 565-566). Hence, for Hartmann the relation between organism and species is an element-system relation analogical to the way that the molecule is a system of atoms. Both the element and its system are relative individuals rather than a relation individual-universal as in the old metaphysics. And, because the system is something more than the mere sum of its elements-as Gestalt psychology was teaching-the life of the species is something more than the sum of the lives of individual organisms (Hartmann 1950, p. 567). ${ }^{27}$

Hennig adopts and applies the model of Russian-dolllike concatenation of elements and systems to biological entities that he finds in Bertalanffy and Hartmann (Hennig 1950, p. 299). Biological categories are all, as he calls them, "supra-individual wholes" (überindividuelle Ganzheiten) (p. 299). Like Hartmann, Hennig conceives of species and higher-order biological categories as supraindividuals. Now, to say that something is a "supra-individual" is to say that it is an individual of an order of magnitude higher than that of concrete individual organisms. But an individual of a higher-order is still an individual. Later, in Phylogenetic Systematics, Hennig says "there can be no doubt that all the supra-individual categories (überindividuellen Kategorien), from the species to the highest category rank, have individuality and reality (Individualität und Realität)" (1966, p. 81; 1982, p. 85).

Hennig gives credit to Hartmann for attributing individuality to the biological categories. As he says, "there is unquestionably a distinct difference between what in systematics are simply called individuals and the "supraindividual' group-categories (überindividuellen Gruppenkategorien), to which N. Hartmann and others also attribute individuality (Individualität)" (1966, p. 82, translation modified; 1982, p. 86). These passages provide support for the claim that Hennig borrowed, or at least sought support in, the idea that species are supra-individuals as he found it in Hartmann "and others." It is also evidence for the claim that Hennig felt compelled to show that his explanation conforms to Hartmann's ontology. This suggests that Hennig used Hartmann's concept of "species" as "supra-individual" to build a metaphysical foundation for the biological categories of phylogenetic systematics.

We have seen that Hennig adopts from Hartmann the thesis that species are individuals. But to say that species are individuals is only giving half of the answer to the question "What is a species?" Affirming that species are individuals only tells us that they are neither universals, nor names, nor concepts. But this does not tell us what ontological category they belong to. Are species individual

\footnotetext{
${ }^{27}$ For a presentation and discussion of Hartmann's definition of species see Tremblay (2011, pp. 125-139).
}

substances? Individual aggregates of substances? Individual qualities? Individual processes? To fully answer the question of species one must not only determine whether they are individuals or universals, but also what ontological category they belong to. As Hamilton says, to define something as an individual "leaves a lot of ground uncovered" (2011, p. 9).

Rieppel answered that for Hennig species are not only individuals, but also "systems of causal interactions" (2007, pp. 354, 357). Rieppel equated this view with the conception that species are events, and said that Hennig adopted this conception from Hartmann. In Rieppel's words, "For Hennig (1950, pp. 5, 23), the 'animated natural things' were 'systems of causal interactions', a view he found articulated by Hartmann (1912, p. 17)" (2007, p. 354$).{ }^{28}$ When he says that Hennig took from Hartmann the view that things are "systems of causal interactions," Rieppel is referring to the following citation from Grundzüge einer Theorie der Phylogenetischen Systematik: "Die Naturgegenstände sind daher nichts anderes als ein System von Wirkungen" (Hennig 1950, p. 5). ${ }^{29}$ We may

\footnotetext{
${ }^{28}$ See also: "For Hennig ... biological entities that are complex wholes at whatever hierarchical level are not substantial, but 'dynamic systems of causal interactions' (Hartmann 1912, p. 17; Hennig, 1950, p. 5)" (Rieppel 2007, p. 354). "Hennig (1950), p. 5 adopted the notion of a neutral 'animated natural thing' as a dynamic system of causal interactions from Hartmann (1912), p. 17" (Rieppel 2007, pp. 357-358).

${ }^{29}$ Rieppel seems to think that the quote comes from Hartmann's Philosophische Grundfragen der Biologie (1912), but in fact Hennig is quoting J. W. Harms (1934, p. 188). The reference says "(zit. nach Harms 1934, p. 188)." J. W. Harms is a German biologist and the quoted book is Wandlungen des Artgefüges: Unter natürlichen und künstlichen Umweltbedingungen, Leipzig: Johann Ambrosius Barth, 1934. The only work from Hartmann that figures in Harms' list of references is Das Problem des geistigen Seins, Berlin/Leipzig: Walter de Gruyter, 1933. But the quote is not to be found in Das Problem des geistigen Seins. Instead, the quote resembles a sentence from Philosophische Grundfragen der Biologie, where Hartmann writes "Naturgegenstand ist eben nichts anderes als ein System von Wirkungen" (Hartmann 1912, p. 17). So Harms' quote could be a mistaken citation of Philosophische Grundfragen der Biologie. This explanation is supported by the fact that previously on the same page Harms quotes another passage from Hartmann that we find as is in Philosophische Grundfragen der Biologie: "Natur nichts anderes als der unendliche Komplex von Kausalreihen ist" (Hartmann 1912, p. 16). But it turns out that these two quotes also appear in Max Hartmann's Biologie und Philosophie, pp. 6-7. Indeed, in the latter book Max Hartmann quotes Nicolai Hartmann as follows: "Natur ist nichts anderes als der unendliche Komplex von Kausalreihen" (N. Hartmann, Philosophische Grundfragen, 1912, p. 16) and on the next page "Naturgegenstand ist eben nichts anderes als ein System von Wirkungen" (N. Hartmann 1912, p. 16). So it seems like we have the following string of indirect quotation: Hennig (1950, p. 5) quotes Harms (1934, p. 188), who quotes Max Hartmann (1925, pp. 6-7), who quotes Nicolai Hartmann (1912, pp. 16-17). Rieppel (2007, pp. 353-354; 357-358) seems to have assumed that the quote came directly from Philosophische Grundfragen der Biologie despite the reference mistake and the slight difference between the quote and
} 
translate this by "The objects of nature are thus nothing else than systems of causal interactions." (Note that this quote will later be absent from Phylogenetic Systematics.) Rieppel seems to infer-based on the assumption that Hennig thinks of biological categories as "objects of nature" - that Hennig also thinks of all biological categories as systems of causal interactions.

A passage from Hennig's "Probleme der biologischen Systematik" brings some support to Rieppel's reading: "the group-categories of a higher-order can face their environment as unities of causal interactions" (Hennig 1947, p. 279). ${ }^{30}$ If the expressions Systeme von Wirkungen and Wirkungseinheiten have-for Hennig-the same meaning, then we may infer that the expression Systeme von Wirkungen indeed applies-as Rieppel thinks-to all biological categories (Hennig 1966, p. 82; 1982, p. 86).

But there is a problem with the claim that Hennig thinks of biological categories as systems of causal interactions; it contradicts the passage of Phylogenetic Systematics where he opposes Bertalanffy's view that individuals are "unities of causal interactions" to Hartmann's view according to which some biological categories are individuals despite not being "unities of causal interactions" (Hennig 1966, p. 82). In this passage, Hennig sides with Hartmann because this allows him to say that all biological categories are individuals (although it is difficult to identify the temporal boundaries of groups of asexually reproducing organisms) even if not all of them are unities of causal interactions. Let me remind you that Hennig said "There can be no doubt that, like the higher categories of the phylogenetic system or of any other divisional hierarchy, they [sc., species] have 'place and duration in time'. It is questionable, however, whether species can be regarded as unities of causal interactions (Wirkungseinheiten) within their environments" (Hennig 1966, p. 83, translation modified and my italics; 1982, p. 86).

True, Hennig also describes the species as an "independent reproductive community" (1966, p. 58). And, since sexual reproduction requires causal interaction, the members of sexually reproducing communities are necessarily in causal interaction with one another. And Hennig makes this inference, too: "That there are forces acting 'inwardly' to hold their components together follows from the definition of the species as a 'reproductive community"” (1966, p. 83). But he also admits that this is not true of all biological categories: it is not true of "those

Footnote 29 continued

the text of Philosophische Grundfragen der Biologie. But it is more likely that Harms was in fact quoting Nicolai Hartmann via Max Hartmann

30 “... die Gruppenkategorien höherer Ordnungsstufe ihrer Umwelt als Wirkungseinheiten gegenüberstehen können" (Hennig 1947, p. 279). categories-also called species-that consist of complexes of incompletely isolated vicarying reproductive communities" (1966, p. 83). Since not all biological entities are systems of causal interactions, then it cannot be their most general feature.

Either Hennig is inconsistent or his view of biological categories evolved between the 1947-1950 period and 1961, which is the year when the manuscript of Phylogenetic Systematics was completed (Schlee 1978, p. 383). The latter hypothesis would explain why the passage Hennig cited in Grundzüge einer Theorie der Phylogenetischen Systematik is absent from Phylogenetic Systematics. ${ }^{31}$ Whatever the key to this riddle might be, Hennig adopts from Hartmann "and others" the view that biological categories-from the species upward-are supra-individuals.

\section{Levels of Reality and Their Kinds of Law}

I now turn to the examination of a group of two closely interrelated theses: (1) the thesis that there are levels of reality, and (2) the thesis that different levels may be subject to different kinds of law, thus requiring different kinds of explanation.

As I wrote before, Hartmann identifies four levels of reality, which are groups of categories related by relations of superposition (Überbauung) and superformation (Überformung). Level $x$ is superposed on level $y$ if and only if level $x$ depends on level $y$ without being constituted by categories belonging to level $y$. In contrast, level $x$ is superformed on level $y$ if and only if level $x$ depends on level $y$ and is partially constituted by categories belonging to level $y$. This being said, for Hartmann, the psychic is superposed on the organic, and the organic superformed on the inorganic. Every level contains categories that are not present at the lower level or levels - this is what Hartmann calls "categorial novelty."

Because of the phenomenon of categorial novelty, Hartmann insists that each level may be subject to its own set of laws and thus may require a different kind of explanation. For instance, no causal process at the inorganic level seems to have a telos, i.e., a purpose. This is not so evident at the organic level where organisms and their parts seem to have unconsciously determined purposes. For instance, organs seem to have the function of preserving the equilibrium of the whole organism. At the higher levels, however, some purposes are consciously and freely posited and involve the selection of a means to achieve a

\footnotetext{
31 I am referring to this quote: "Die Naturgegenstände sind daher nichts anderes als ein System von Wirkungen" (Hennig 1950, p. 5).
} 
goal. This example shows that causal accounts at some levels should involve teleological explanations and that some should not. Thus, for Hartmann, each level has its own set of laws, and these differences should be taken into consideration when providing explanations. ${ }^{32}$

These two Hartmannian theses were adopted by many 20th-century German-speaking natural scientists. Among them were Bertalanffy, ${ }^{33}$ Lorenz, ${ }^{34}$ and Hennig. In his (1950) work, Hennig discusses Lloyd Morgan's theory of emergent evolution. Emergent evolution is the theory that the stages of evolution are not merely the results of a continuous evolutionary stream, but emerge from one another in discrete steps (Morgan 1923). Hennig quotes Bertalanffy on Morgan's view:

\footnotetext{
"In emergent evolution, every stage — atom, molecule, colloidal unit, biokyl, cell, multicellular organism, society of organisms - obtain characteristics that cannot be derived from those of the underlying elements, in contrast to the mere resultant" (von Bertalanffy I, p. 94). We find this account in von Bertalanffy and others (for instance, Nicolai Hartmann). ${ }^{35}$
}

Hennig associates Morgan's theory with the thought of Bertalanffy and Hartmann. There is indeed a great deal of overlap between Morgan, Hartmann, and Bertalanffy. But Bertalanffy and Hartmann's views differ from Morgan's in that neither conceive their theories in evolutionary terms. ${ }^{36}$

\footnotetext{
${ }^{32}$ For a discussion of the levels of reality and their laws, see Hartmann (1942, Chapt. viii).

33 The Bertalanffy scholars Pouvreau and Drack said that Hartmann and Bertalanffy both started talking about levels in 1925, suggesting that Hartmann couldn't have influenced Bertalanffy (Pouvreau and Drack 2007, p. 312). But Hartmann began speaking of levels (Stufen) at least as early as 1912 (pp. 48, 52, 55, 56, 72, 74, 78, 79, etc.). Pouvreau later rectified this $(2009$ b, p. 113 , note 49 ).

${ }^{34}$ See Lorenz's chapter on Hartmann's theory of levels (1977, pp. 36-43).

35 “'In der emergent evolution erlangt jede Stufe: Atom, Molekül, kolloidale Einheit, Biokyl, Zelle, vielzelliger Organismus, Staatenbildung von Organismen, Eigenschaften, welche aus denen der untergeordneten Elemente nicht abgeleitet werden können-im Gegensatz zur bloßen Resultante' (v. Bertalanffy I, p. 94). Nun gelten diese Ueberlegungen bei v. Bertalanffy u. a., (Verwandtes z. B. auch bei Nicolai Hartmann)" (Hennig 1950, pp. 298-299). Hennig omitted the Anführungszeichen (German quotation marks) around "emergent evolution," "Biokyl," and "Resultante," and changed Bertalanffy's expression "neue Besonderheiten" for "Eigenschaften." Such mistakes may have been caused by his secondhand access to the texts. Indeed, Hennig wrote the book during the war when he was deployed abroad (Poland, France, Denmark, Russia, and Italy). He did not have access to his books, so he asked his wife to copy him book passages and to send them by mail (Schlee 1978, pp. 380-382).

36 As Helmut Kuhn says, for Hartmann "[e]ach one of the higher levels shows, compared with the lower one, novel features, i.e., structural peculiarities in no wise predetermined by categories located further down - an idea which may be regarded as a static version of
}

As Hartmann says, "ontology, on pain of relapsing into speculative construction, must not assume the task of mapping out the evolutionary process" (1953, p. 109). ${ }^{37}$ Hartmann agreed with the theory of evolution, but conceived his theory of levels as a static snapshot of the basic relations of existential dependence within reality. For Hartmann, the theory of evolution and the theory of levels are two different kinds of representation of reality involving different kinds of relation not to be confused with one another. What is genetically prior is not necessarily also existentially prior: the father is genetically prior to the son, but once the son has come into being he can exist without the father. ${ }^{38}$

Bertalanffy understood levels in Hartmann's static sense rather than in Morgan's emergentist sense. As the Bertalanffy scholars Pouvreau and Drack say,

Contrary to most of the interpretations, Bertalanffy's conception is not an emergentism in the proper sense (Lloyd Morgan 1923), notwithstanding the similarities. The latter (more related to Fechner's philosophy and to N. Hartmann's “theory of categories" (1912, 1964) than to English philosophers) lie in the fact that Bertalanffy from the beginning admits a stratification of reality, of which the main levels are the physical, the biological, the psychological and the cultural ones. (Pouvreau and Drack 2007, p. 308)

In spite of Hartmann's and Bertalanffy's non-emergentist theories of levels, Hennig understands the interrelation of taxonomical categories on the basis of the model of emergent evolution. In the same way that stages of evolution emerge from each other, he conceives the higher taxonomical categories as groups emerging from subgroups of a shorter time span (1950, p. 299).

Moreover, like Hartmann, Hennig admits that the fact that the divisions between these levels are not gradual, but discrete, leaves open the possibility that each level has its own kinds of law. And, since it is possible that each taxonomic level has its own set of laws, philosophers and scientists should expect to have to provide different kinds of account for each of them. As Hennig says:

Footnote 36 continued

Lloyd Morgan's principle of 'emergent evolution'” (1951, p. 306, my italics).

${ }^{37}$ For Hartmann's discussion of this issue, see Hartmann (1953, pp. 109-113). See also Friedrich Schneider: "Nicolai Hartmann did not believe in the evolution of the three higher levels from the lowest level. ... In contrast to the emergent evolutionist, Hartmann is content with an 'analytical ontology"' (1958, p. 169).

${ }^{38}$ In Hennig's defense, however, Hartmann himself authorized the genetic interpretation of the theory of levels: "Do the categorial laws of stratification and dependence, completely neutral as they are in regard to all genetic questions, admit of a genetic interpretation? This question can be answered affirmatively without any hesitation." (Hartmann 1953, p. 110). 
it cannot be overlooked that there are essential differences between the individuals, which exist as such even in everyday language, and the "supra-individual," particularly the supraspecific, taxonomic categories. These differences are probably not merely of a gradual nature in the sense that, measured with the yardstick of our human proportion relations (Proportionsverhältnisse), one is naively given (naivrealistisch gemessen) as individuals whereas the other must first be determined as such. On the contrary, it is often emphasized (N. Hartmann 1942, for example) that we cannot assume that the laws ascertained for a particular level (Schicht) in the graded structure of things (Stufenbau der Dinge) are also valid for other (e.g., higher) levels (Schichten). This is true even when things of the higher levels appear to be "composed" of components that resemble or are identical with the individual things of the lower levels. (Hennig 1966, pp. 81-82, translation modified; 1982, p. 85)

Hennig acknowledges that-as "emphasized" by Hartmann-we must not generalize that the laws known to govern one level also govern other levels, and this regardless of whether the said levels stand in relations of superformation or superposition.

In Hennig's phylogenetic taxonomy the semaphoront is the category that constitutes the lowest level. The organism is constituted of and emerges from the semaphoront; the species is constituted of organisms and emerges from them; the monophyletic taxa emerge from the species; etc. These are taxonomical levels, which means that they are related by relations of generic inclusion. In contrast, Hartmann's levels are related by relations of superformation and superposition, which are relations of existential dependence. Without the inorganic, there is no organic, without the organic, no psychic, etc. There is an important difference between the two kinds of levels. In Hartmann's theory, a higher level does not include the lower one (at least not the totality of the lower one), whereas a higher taxonomic category includes the lower one (in its totality). Not all inorganic things are part of living beings, but all dogs are caninae. Since their elements are linked by different kinds of relations, the one kind of sequence cannot be confused with the other. So it is fallacious to assume that these two kinds of sequence can be collapsed into a single one.

Hennig-perhaps mistakenly, perhaps creatively-took aspects of Bertalanffy's and Hartmann's theories of levels and applied them to the taxonomic levels of phylogenetic systematics. In any case, we can say that Hartmann's theory of levels had a partial impact on the development of phylogenetic systematics. Rieppel also recognized the importance of Hartmann's theory of levels for Hennig:
Hennig ... emphasized that ... monophyletic taxa might have properties that are emergent and for that reason cannot be the mere result of the summation of the properties of the included parts. If monophyly is a relational property that emerges from species-lineage splitting, then species themselves cannot be monophyletic .... It is not the aggregation of species that descended from a common ancestor that results in a monophyletic assemblage. It is a species-lineage splitting and splitting again from which emerges the monophyletic taxon as a new entity of higher complexity. One of the modern philosophers writing on emergence was Nicolai Hartmann, another important influence on Hennig (Rieppel 2006, 2007). For Hartmann, emergence created a categorial novum, and for Hennig, the monophyletic taxon was such a new category that emerged from species-lineage splitting. (Rieppel 2009, p. 315)

Thus, regardless of whether Hennig has misunderstood Hartmann's theory of levels or creatively applied it to the analysis of taxonomical categories, we may conclude that Hartmann's philosophy played some role in the development of phylogenetic systematics in this last respect, too.

\section{Conclusion}

Hennig sought in Hartmann's ontology foundational elements for his newly developed phylogenetic systematics, and in his search he relied on at least four basic Hartmannian theses: that what is real is what is temporal, that biological categories are individuals by virtue of having duration, that biological categories are supra-individuals, and that there are levels of reality the categories of which may obey different kinds of law. These four theses are fundamental to Hennig's phylogenetic systematics. At least two of them-that what is real is what is temporal and that biological categories are individuals by virtue of having duration-were instrumental in overcoming the morphological idealism that was still predominant in German biology at the beginning of the 20th century. This is no small contribution if we consider that "morphology was a very important discipline in pre-Darwinian times, but then lost its importance and is presently nothing but a resource for phylogenetical research" (Claßen-Bockhoff 2001, p. 1164).

I do not intend to downplay the importance of other intellectual figures on Hennig. After all, he also gave a great deal of credit to thinkers such as Max Hartmann, Ludwig von Bertalanffy, and Theodor Ziehen. Rieppel gave preeminence to Bertalanffy for influence on the basis of frequency of citation (2007, p. 345). It may be the case 
that Bertalanffy had a greater overall direct influence. But Nicolai Hartmann was the metaphysician of the bunch, and Max Hartmann and Bertalanffy were already influenced by him in this respect. ${ }^{39}$ The fact that Max Hartmann and, to a lesser extent, Bertalanffy were metaphysically influenced by Nicolai Hartmann and that Hennig was, in turn, influenced by Max Hartmann and Bertalanffy reinforces my claim that Nicolai Hartmann's ontology played-directly or indirectly - a role worthy of consideration in the metaphysical foundation of phylogenetic systematics.

Some of the literature on Hennig belittled its philosophical aspect altogether. Claude Dupuis, for instance, reprimanded Serge Kiriakoff (1963) for emphasizing the philosophical aspects of Hennig's theory. For Dupuis (1978, pp. 13, 28) the sources of Hennig's ideas are not to be sought in philosophy, but rather in the works on dipterology, biogeography, and studies on larvae that were published between the two wars. Of course, the importance of philosophical ideas for Hennig should not be overestimated, but it should not be underestimated either. From what we have seen, it is clear that philosophical ideas played an important foundational role for Hennig and it is

\footnotetext{
39 It is no secret that the theoretical aspect of Max Hartmann's program consisted in applying Nicolai Hartmann's ontology to the field of biology. In his biography of Max Hartmann, Heng-an Chen says that Max Hartmann related closely to Nicolai Hartmann's ontological philosophy and conception of science, especially of biology (2003, p. 40). Max Hartmann's books Biologie und Philosophie (1925) and Die philosophischen Grundlagen der Naturwissenschaften: Erkenntnistheorie und Methodologie (1959) are through and through influenced by Nicolai Hartmann. In fact, they are to a certain extent compendia of (Nicolai-) Hartmannian metaphysics of knowledge and philosophy of science for the use of the biologist. Bertalanffy's debt to Nicolai Hartmann is certainly not as great as Max Hartmann's, but there is nevertheless an influence. The very idea of a "general system theory" was avowedly his own version of what Nicolai Hartmann called the 'theory of categories': "Speaking philosophically, general system theory, in its developed form, would replace what is known as 'theory of categories' (N. Hartmann 1942) by an exact system of mathematical laws" (Bertalanffy 1968, pp. 85-86). As Bertalanffy's biographer David Pouvreau says "Bertalanffy also familiarized himself ... with the thought of other great neo-Kantian philosophers or philosophers of neo-Kantian origin, such as Heinrich Rickert (1863-1936) or Nikolai Hartmann (1882-1950) - whose theory of the stratification of the real and of the 'fundamental categories' he considered a forerunner of his general systemology on a metaphysical level" (Pouvreau 2009a, p. 33). Rieppel himself recognizes this influence: "He [sc., Bertalanffy] was also one of the few biologists who was influenced by Hartmann's (1912) systems-theoretical approach to the philosophy of biology" (Rieppel 2007, p. 351). As to Ziehen, since he was twenty years older than Nicolai Hartmann, we could have expected him not to take Hartmann's work into account. But Ziehen (1939, pp. 146-148) nevertheless devotes a section on Hartmann in the second volume of his Erkenntnistheorie to present and discuss Hartmann's realism as he finds it in Zur Grundlegung der Ontologie. This does not imply an influence, of course, but it testifies that Ziehen was at least a reader of Hartmann and considered his philosophy important enough to be worth discussing in his own work.
}

unseemly that he could have simply extracted the most fundamental ideas of phylogenetic systematics from the specific kinds of empirical studies Dupuis mentions. The present essay has shown incidentally that such an antiphilosophical account of Hennig's theoretical sources must be incomplete and misleading.

Acknowledgments Thanks are due to Keith Peterson, Carlo Scognamiglio, and Barry Smith for valuable comments.

\section{References}

Caponi G (2010) Las masas lamarckianas como clases naturales. Filos Hist Biol 5:295-307

Claßen-Bockhoff R (2001) Plant morphology: the historic concepts of Wilhelm Troll, Walter Zimmermann and Agnes Arber. Ann Bot 88:1153-1172

Darwin C (1859) On the origin of the species by means of natural selection: or, the preservation of favoured races in the struggle for life. John Murray, London

Dupuis C (1978) Permanence et actualité de la systématique: La « systématique phylogénétique » de W. Hennig (historique, discussion, choix de références). Cahiers des nat 43:1-69

Hamilton A (2011) From types to individuals: Hennig's ontology and the development of phylogenetic systematics. Cladistics 27:1-11

Harms J-W (1934) Wandlungen des Artgefüges unter natürlichen und künstlichen Umweltbedingungen. Johann Ambrosius Barth, Leipzig

Hartmann M (1925) Biologie und Philosophie. Julius Springer, Berlin

Hartmann M (1959) Die philosophischen Grundlagen der Naturwissenschaften: Erkenntnistheorie und Methodologie, 2nd edn. Fischer, Stuttgart

Hartmann N (1912) Philosophische Grundfragen der Biologie. Vandenhoeck \& Ruprecht, Göttingen

Hartmann N (1926) Ethik. de Gruyter, Berlin

Hartmann N (1933) Das Problem des geistigen Seins. Untersuchungen zur Grundlegung der Geschichtphilosophie und der Geisteswissenschaften. de Gruyter, Berlin

Hartmann N (1935) Zur Grundlegung der Ontologie. de Gruyter, Berlin

Hartmann N (1938) Zeitlichkeit und Substantialität. Blätter für dtsch Philos 12:1-38

Hartmann N (1940) Der Aufbau der realen Welt. Grundriß der allgemeinen Kategorienlehre. de Gruyter, Berlin

Hartmann N (1942) Systematische Philosophie. Kohlhammer, Stuttgart

Hartmann N (1949) Alte und neue Ontologie. Actas del Primer Congreso Nacional de Filosofía, vol 2, Mendoza, Argentina, marzo-abril, pp. 782-787

Hartmann N (1950) Philosophie der Natur: Abriß der speziellen Kategorienlehre. de Gruyter, Berlin

Hartmann N (1953) New ways of ontology. Regnery, Chicago

Heng-an Chen (2003) Die Sexualitätstheorie und "Theoretische Biologie" von Max Hartmann in der ersten Hälfte des zwanzigsten Jahrhunderts. Franz Steiner, Wiesbaden

Hennig W (1947) Probleme der biologischen Systematik. Forschungen und Fortschritte 21-23:276-279

Hennig W (1950) Grundzüge einer Theorie der phylogenetischen Systematik. Deutscher Zentralverlag, Berlin

Hennig W (1966) Phylogenetic systematics. University of Illinois Press, Urbana, IL

Hennig W (1982) Phylogenetische Systematik. Hennig W (ed). Parey, Berlin 
Kiriakoff SG (1963) Les fondements philosophiques de la systématique biologique. In Classification dans les sciences. Duculot, Gembloux, pp 61-88

Kuhn H (1951) Nicolai Hartmann's ontology. Philos Quart 1:289-318

Lorenz K (1977) Behind the mirror: a search for a natural history of human knowledge. Harcourt Brace Jovanovich, New York

Mittwoch U (2002) 'Clone': the history of a euphonious scientific term. Med Hist 46:381-402

Morgan CL (1923) Emergent evolution. Holt, New York

Pouvreau D (2009a) The dialectical tragedy of the concept of wholeness: Ludwig von Bertalanffy's biography revisited. ISCE Publishing, Lichtfield Park

Pouvreau D (2009b) «Systémologie générale », perspectivisme et humanisme. Sciences et techniques en perspective 12(1):99-226

Pouvreau D, Drack M (2007) On the history of Ludwig von Bertalanffy's "General Systemology", and on its relationship to cybernetics. Int J Gen Syst 36:281-337

Reif W-E (2010) Hennig's threefold relationalism. Neues Jb Geol Paläontol Abh 255:213-236

Richter S, Meier R (1994) The development of phylogenetic concepts in Hennig's early theoretical publications (1947-1966). Syst Biol 43:212-221

Rieppel O (2003) Semaphoronts, cladograms and the roots of total evidence. Biol J Linn Soc 80:167-186

Rieppel O (2006) On concept formation in systematics. Cladistics 22:474-492

Rieppel O (2007) The metaphysics of Hennig's phylogenetic systematics: substance, events and laws of nature. Syst Biodivers $5: 345-360$
Rieppel O (2009) Hennig's enkaptic system. Cladistics 25:311-317

Schlee D (1978) In memoriam Willi Hennig 1913-1976. Eine biolgraphische Skizze. Entomol Germanica 4:377-391

Schneider F (1958) Realism in recent German philosophy. Philos Phenomenol Res 19:143-182

Tremblay F (2011) Nicolai Hartmann's definition of biological species. In: Poli R, Scognamiglio C, Tremblay F (eds) The philosophy of Nicolai Hartmann. de Gruyter, Berlin, pp 125-139

von Bertalanffy L (1968) General system theory: foundations, development, applications. Braziller, New York

Wiley EO (1981) Phylogenetics: the theory and practice of phylogenetic systematics. Wiley, New York

Wiley EO, Mayden RL (1985) Species and speciation in phylogenetic systematics, with examples from the North American fish fauna. Ann Mo Bot Gard 72:596-635

Wilkins JS (2009) Species: a history of the idea. University of California Press, Berkeley

Ziehen T (1915) Die Grundlagen der Psychologie. I. Buch. Erkenntnistheoretische Grundlegung der Psychologie. Teubner, Leipzig

Ziehen T (1934) Erkenntnistheorie. Erster Teil. Allgemeine Grundlegung der Erkenntnistheorie. Spezielle Erkenntnistheorie der Empfindungstatsachen einschließlich Raumtheorie. Fischer, Jena

Ziehen T (1939) Erkenntnistheorie. Zweiter Teil: Zeittheorie. Wirklichkeitsproblem. Erkenntnistheorie der anorganischen Natur (erkenntnistheoretische Grundlagen der Physik). Kausalität. Fischer, Jena 